2. To: (Receiving Organization)

W-Tank Farm Engineering

5. Proj./Prog./Dept./Div.:

Portable Leak Detector Stations

8. Originator Remarks;

This EDT transmits the release of the Supporting Document, HNF-4348, Rev. 0, "Analysis of Bracket Assembly for Portable Leak Detector station."

11. Receiver Remarks:

11A. Design Baseline Document?

? Yes

No

3. From: (Originating Organization)

Operational Equipment Engineering

6. Design Authority/Design Agent/Cog. Engr.:

H. H. Ziada

\begin{tabular}{|l} 
\\
1 \\
\hline
\end{tabular}

\begin{tabular}{|l|l|}
\hline 15. \\
\hline $\begin{array}{c}\text { (A) } \\
\text { Item } \\
\text { No. }\end{array}$ & (B) Document/Drawing No. \\
\hline 1 & HNF -4348 \\
\hline & \\
\hline & \\
\hline & \\
\hline & \\
\hline & \\
\hline & \\
\hline
\end{tabular}

16.

\begin{tabular}{|c|l|}
\hline Approval Designator (F) & \\
\hline E, S, Q, O OR N/A & 1. Approval \\
(See WHC-CM-3-5, & 2. Release \\
Sec. 12.7) & 3. Information \\
\hline
\end{tabular}
17.

$$
\begin{array}{|}
\hline \\
\hline \\
\hline \\
\hline \\
\hline
\end{array}
$$

\begin{tabular}{|}
\hline \\
\hline \\
\hline \\
\hline \\
\hline
\end{tabular}




\section{ANALYSIS OF BRACKET ASSEMBLY FOR PORTABLE LEAK DETECTOR STATION}

Hassan H. Ziada

Numatec Hanford Corporation

Richland, WA 99352

U.S. Department of Energy Contract DE-AC06-96RL13200

$\begin{array}{lll}\text { EDT/ECN: } 624016 & \text { UC: } 2000 \\ \text { Org Code: } & 85600 & \text { Charge Code: } 108968 \\ \text { B\&R Code: } & \text { EW3130000 } & \text { Total Pages: } 27\end{array}$

Key Words: Leak Detector Rack, Bracket Assembly, Leak Detector Station, Tank Farms, Stress Analysis,

Abstract: This Supporting Document Presents Structural and Stress Analysis of a Portable Leak Detector station for Tank Farms. The results show that the bracket assembly meets the requirements for dead load and natural phenomena hazards loads (seismic and wind).

TRADEMARK DISCLAIMER. Reference herein to any specific commercial product, process, or service by trade name, trademark, manufacturer, or otherwise, does not necessarily constitute or imply its endorsement, recommendation, or favoring by the United States Government or any agency thereof or its contractors or subcontractors.

Printed in the United States of America. To obtain copies of this document, contact: Document Control Services, P.O. Box 950, Mailstop H6-08, Richland WA 99352, Phone (509) 372-2420; Fax (509) 376-4989.

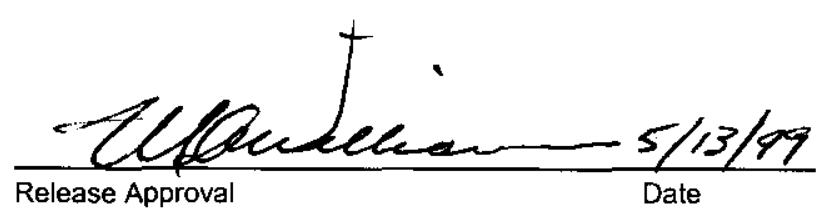

Approved For Public Release

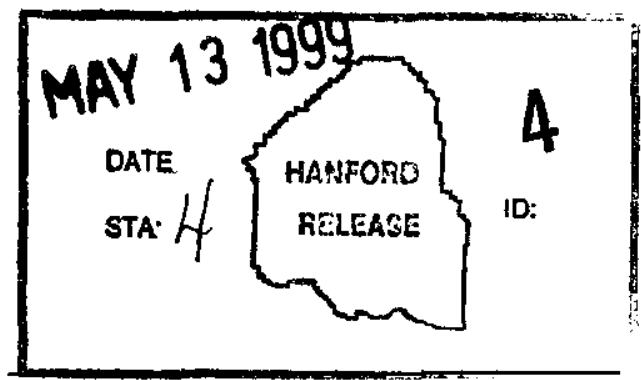

Release Stamp 
HNF-4348, Rev. 0

\title{
ANALYSIS OF BRACKET ASSEMBLY FOR PORTABLE LEAK DETECTOR STATION
}

\author{
May 1999 \\ By \\ H. H. Ziada \\ Numatec Hanford Corporation \\ Richland, Washington
}

For

Lockheed Martin Hanford Corporation

Richland, Washington 


\section{CHECKLIST FOR INDEPENDENT REVIEW}

Document: Analysis of Bracket Assembly for Portable Leak Detector Station

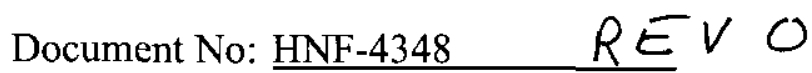

Author: $\quad$ Hassan H. Ziada

$\underline{\text { Yes }} \quad \underline{\text { No }} \quad \underline{N / A}$

[X] [ ] [ ] Problem completely defined.

W [ ] [ ] Necessary assumptions explicitly stated and supported.

[ ] [ ] \ Computer codes and data files documented.

[ [ ] [ ] Data used in calculations explicitly stated in document.

L] [ ] [ ] Data checked for consistency with original source information as applicable.

W [ ] [ ] Mathematical derivations checked including dimensional consistency of results.

L [ ] [ ] Models appropriate and used within range of validity or use outside range of established validity justified.

L] [ ] [ ] Hand calculations checked for errors.

[ ] [ ] $[\varnothing]$ Code run streams correct and consistent with analysis documentation.

[ ] [ ] $\quad \backslash]$ Code output consistent with input and with results reported in analysis documentation.

W [ ] [ ] Acceptability limits on analytical results applicable and supported limits checked against sources.

X] [ ] [ ] Safety margins consistent with good engineering practices.

[X] [ ] [ ] Conclusions consistent with analytical results and applicable limits.

X] [ ] [ ] Results and conclusions address all points required in the problem statement.

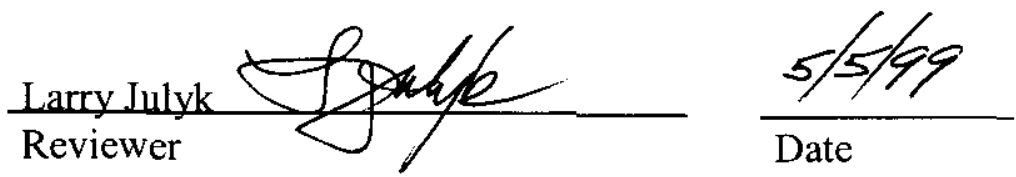


HNF- 4348, Rer.o

ANALYTICAL CALCULATIONS

Page of 24

Subject Portable Leak Deter tor Station.

Originator

Checker

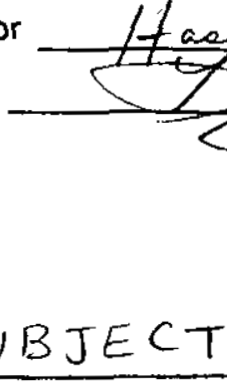

Date

Date

galle

$$
\frac{4-12-25}{4 / 22 / 69}
$$

TABLE OF CONTENTS
SUBJECT

1.0 INTRODUCTION

i. OBJECTIVE

1.2 EVALUATION

2.0 CONCLUSIONS

3.0 CONFIGURATION AND MATERIAL

4.0 CRITERIA AND LOADING

4.1 CRITERIA

4.2 ALLOWABLE STRESSES AND LOADS 7

4.3 LOADS AND AREAS

5.0 ANALYSIS

SI OVERTURNING

$5.2 S L I D I N G$

5.3 CHANNEL STRESSES (PION)

5.4 FITTING SCREWS STRESSES

5.5 WELD STRESSES

5.6 MISSILE IMPACT

6.0 OPEN ITEMS

7.0 REFERENCES
PAGE NO.

2

3

4

5

7

7

10

14

14

15

16

17

18

20

21

22

BD-6400-060.1 (07/93) 
INF -4348 , Rev.0

ANALYTICAL CALCULATIONS

Page 2 of 24

Subject Portable Lek Detector station

originator Hagen - Zen

Checker

Date

Date

ANALYSIS OF BRACKET ASSEMBLY FOR

PORTABLE LEAK DETECTOR STATION

1.O INTRODUCTION

This supporting Document presents the structure and stress andingsis evaluating of a bracket assembly for a potable leak detection station.

This analysis supports the devin of a portable interinsically sofeleak detector station provided in Engineering Charge Notice (ECN) number 652131 (ECN,1B9y) and drawing number H-2-34965, Rev.3 5 (LMHC, 1999), and drawing number $H-2-815302$, Rev .O (WHC, 1993).

1.1 OBJECTIVE

The objective of this analysis is to ensure that the bracket assembly is structuraling quaffed to withstand the natural phenomena hazards loads (seismic and wind) and dead weight in accordance with basic criteria documents and stamilards.

BEST AVAILABLE COPY

BD-6400-060.1 (07/93) 


$$
\text { HNF-4348, Rer.o }
$$

ANALYTICAL CALCULATIONS

Page 3 of 24

Subject Portable Lex k Detector station

Originator

Checker

$$
\text { Date } \frac{4-12-19}{4 / 22 / 99}
$$

1.2 EVALUATION

The bracket assembly is supporting a safety class leak detector. The bracket is considered as a performance category $3(P C 3)$ structure for wind lords. However, the earthquake loads are evaluated as a P CI (general service) structure, because there are no safety class or safety significant functions to rely on the structure surviving a seismic event (Timminss,1998). The seismic and wind lords were determined in accordance with boric criteria documents; HNF(1997), DOE 6430.1A (1989), UCRL-15910 (1990), ASCE 7-95(1995), and UBC(1994).

The structural components were errbated in accordance with AISC (1989) dexynstress allowable. No credit was taken for the $1 / 3$ increase of allowable for wind and seismic hoods as specified in Alsc(1989).

The channels and fitting allowable loads are provided in UNISTRUT (1995) Catalog.

(1) UNISTRUT, trade name of UNISTRUT Metal Framing, UNISTRUT Corporation, Unistrut Diversified Products, Wayne, Michigan.

BD-6400-060.1 (07/93) 
INF- $4348, R$ er. 6

ANALYTICAL CALCULATIONS

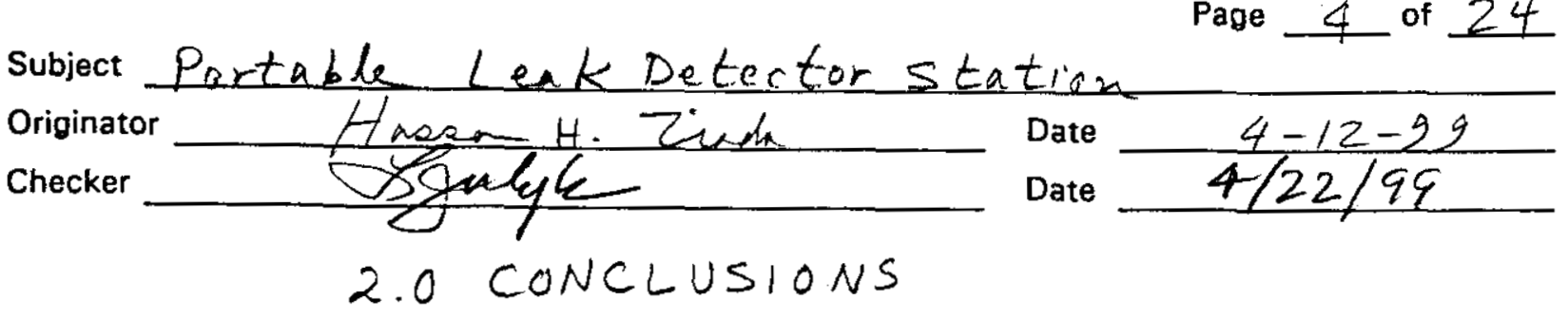

A Ul components of the bracket areembing meat the requirements for dead load and notweral phenomena hazards loads ( Seismic and wind) in accordance with the requirements of HNF(19g7), and the assembly is qualified for use ns a PC 3 structure (-with PCI for seismic).

The structural components were ewolusted in accordance with AISC $(1989)$ design stress

The assembly will not overturn or slide due to seismic or wind loads.

8D-6400-060.1 (07/93) 


$$
\text { NF }-4348, R \text { RN. }
$$

ANALYTICAL CALCULATIONS

Page 5 of 24

subject Portable Leak Detector Stitam

Originator Haven H Rid

Checker

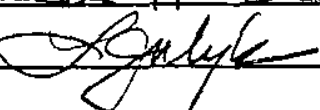

Date

Date

$$
\frac{4-12-99}{4 / 22 / 99}
$$

3.O CONFIGURATION AND MATERIAL

The configuration of the assembly is shown in Figure 1. The dimensions and weights of the structural components are provided in UNISTRUT(IgSS).

The station is set above ground.

The material of the structural chasundo and fittings is ASTM A 446, Grade A, Pre-gndunnized steed. The yield strength $\left(S_{y}\right)$ is $33,00016 / \mathrm{in}^{2}$ and the ultimate strength (So) is $45,00016 \mathrm{f} / \mathrm{in}^{2}$

The fastening SCrews are made of ASTM A307, Grade $A$, with an ultimate strength $\left(s_{u}\right)$ of $60,000 \mathrm{lb} / \mathrm{in}^{2}$

$B D-6400-060.1(07 / 93)$ 


$$
\text { HNF }-4348, \text { Res.0 }
$$

\section{ANALYTICAL CALCULATIONS}

Subject Portable Leak Detector statim
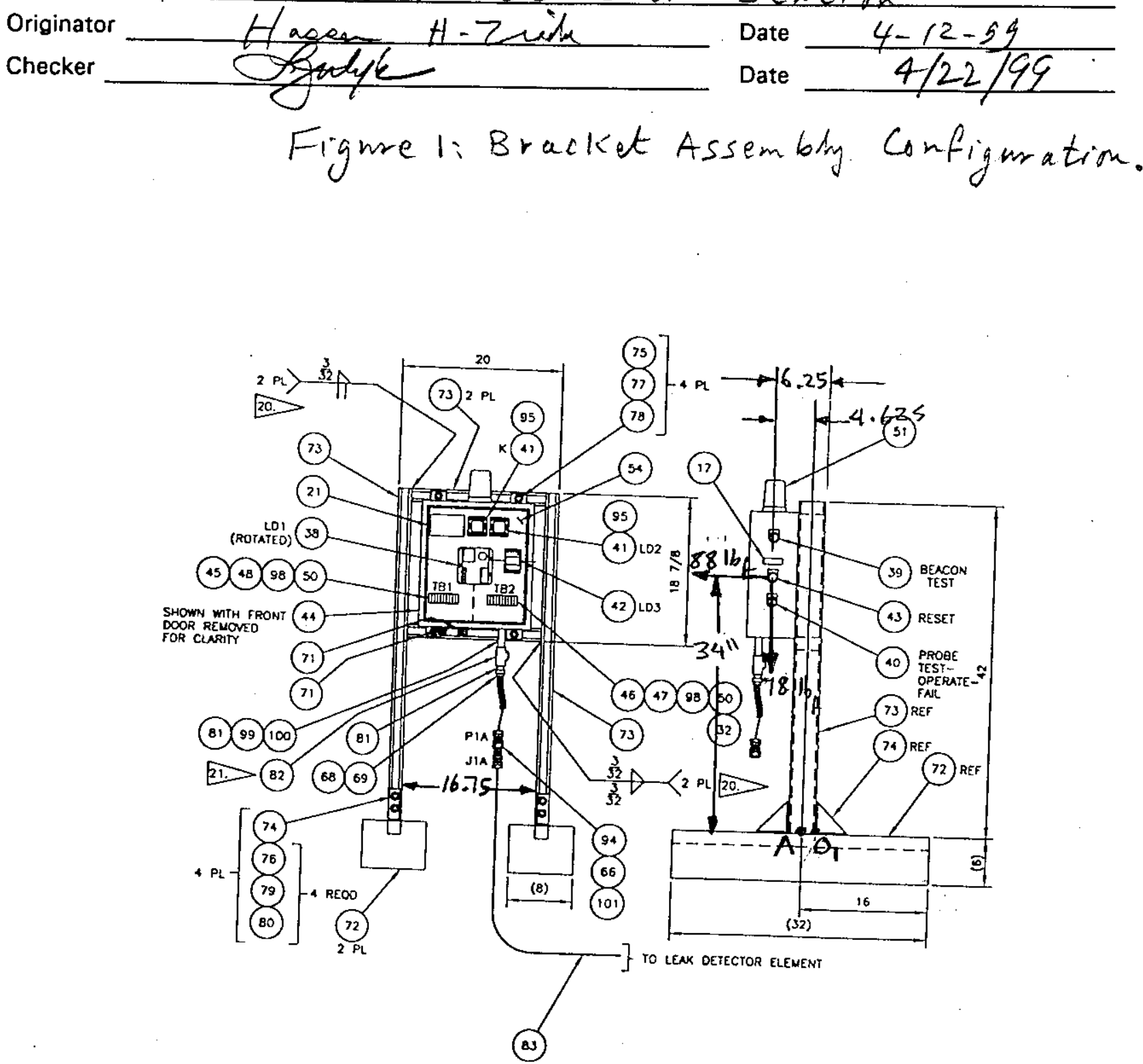

BEST AVAILABLE COPY 
HNF -4348 , Rer.o

ANALYTICAL CALCULATIONS

Page 7 of 24

Subject Partable Leak Detertor Statim

Originator

Checker

Date

$\frac{4-12-59}{4 / 22 / 99}$

4.0 CRITERIA AND LOADING

The brackit asiambly ho been evilusted to withstand dead lood aind notwroed phemomena

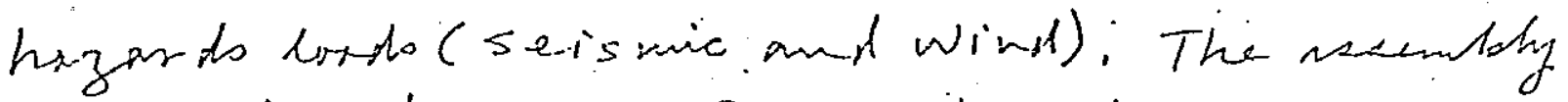
is analyzed wo a PCB. structure.

4.1 CRITERIA

The structional componento have been eviluitid. in aceordince with AISC (lgrg) allownblestress derigin

No crestit wro titken for the $1 / 3$ incresen allowables for seismic and wind loats (AISC,1gsi).

4.2 allowable stressesiand loAdos

4.2 .1 charinels.

The channels are Carbom Sted ASTM A446 $G R A$ : Theiy are bent ar ound axis $(1-1)$. $(\rho 1001)$

$$
\begin{aligned}
& I_{11}=0.93 \mathrm{in}^{4}, S_{11}=0.572 \mathrm{in}^{3} \\
& I_{22}=0.472 \mathrm{in}^{4}, S_{22}=0.58 \mathrm{in}^{3}
\end{aligned}
$$

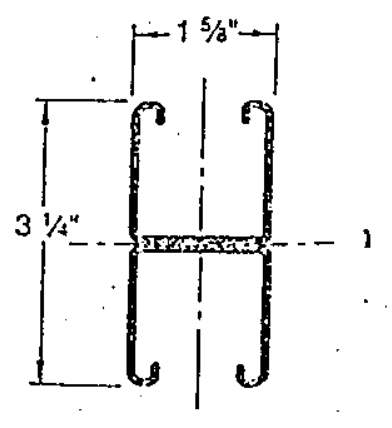


INF -4348, Rev. 0

ANALYTICAL CALCULATIONS

Page 8 of 24

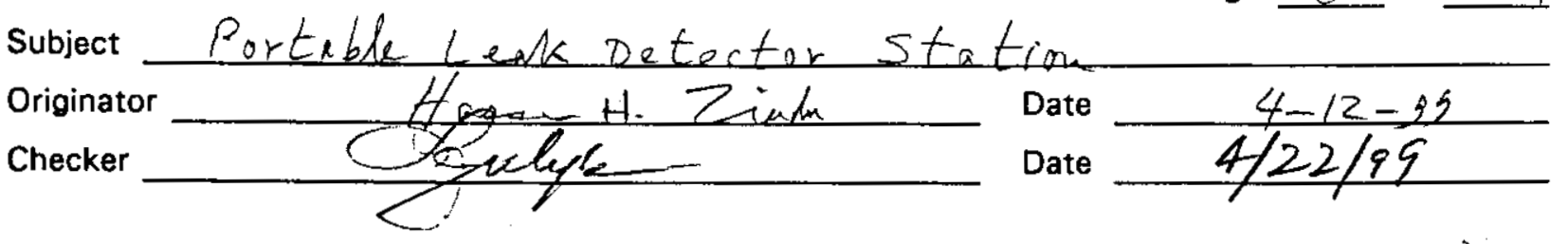

The allowable bending stress around the weak axis is obtained firm AIS C(1989).

$$
\sigma_{b \text { all }}=0.75 \times 5 y=0.75 \times 33,000=24,75016 \mathrm{f} / \mathrm{in}^{2}
$$

This value is conservative than the allowable guin in UNISTRUT (1995).

The allowable moment in UNISTRRUT (1995) for P 1001 is 14,390 in-16f, the models of section $\left(S_{11}\right)$ is $0.5 \pi 2 r^{3}$, this gives an allowable bending stress $\left(\frac{M a x}{511}\right)$ of $25,157 \mathrm{lg} / \mathrm{in}^{2}$.

However, for conservatism, the channels are considered as non compact sections.

The allowable binding stress for nom compact section is $0.6 \times$ Syn.

$$
\left.\sigma_{b} \text { all (non compact }\right)=0.6 \times 33,000=19,80016 \mathrm{f} / \mathrm{in}^{2}
$$

This allowable is need for errhintiri.

BD-6400-060.1 (07/93) 
HNF -4348, Rev. 0

ANALYTICAL CALCULATIONS

Page 9 of 24

Subject Portable Leak Detector Stations

Originator Hose H. Vial

Checker Date Date $4-12-39$

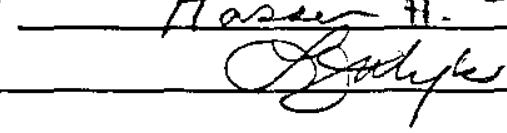

4.2.2 Fittings

The fittings are mode of the some motoring of the channels.

However the UNISTRUT (I9OS), PY.81, provides design hood deter for different correction's.

The P2484 90 degree fitting hoo a load Capacity of $30001 \mathrm{f}$ for 12 gauge chanel.

4.2.3 Fitting Screws

The screws are ASTM A 307 , Code A. The allowable stresses are give in AISC (1989)

Allowable tensile stress $=0.33 \mathrm{Su}=0.33 \times 60,000$

$=19,800 \quad 16 \mathrm{f} / \mathrm{in}^{2}$

Allowable shear 5 tress $=0.17 \mathrm{~S}_{V}=10,200 \mathrm{lb} / \mathrm{in}^{2}$

Assuming the shear force is carried in the thread area.

UNI STRUT (199S), page 69, provides maximum allowable pullout and slip loads as follows:

$1 / 2$-in. nut pull-out blood $=2,000 \mathrm{lb} f ;$ slip load, $=150.16 \mathrm{f}$.

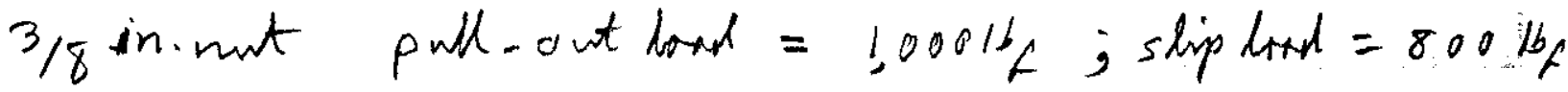

BD-6400-060.1 (07/93) 


$$
\text { INF }-4348 \text {, Rev. } 0
$$

ANALYTICAL CALCULATIONS

Page 10 of 24

Subject Portable LeM Detection Station

Originator

Checker

Hagen H. Zr nh

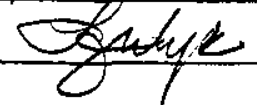

Date

Date
$4-12-39$

$4 / 22 / 99$

4.3 LOADS AND areas

This section presents the weyilts and ares of the assembly. It ale o includes the calculation for wind ant seismic looks.

4.3.1 weyits

Box wert

Equipment inside box. (resumed)

Total box weyht

$$
\begin{aligned}
& 21 \mathrm{kf} \\
& 916 \mathrm{f} \\
& 3016 \mathrm{f}
\end{aligned}
$$

weight of $P 1001$ channels $=\frac{(2 \times 42+2 \times 20)}{12} \times 3.8=401 \mathrm{~b} \mathrm{~A}$ A spume fittings weight $(20 \%$ of chanel $)=81 \mathrm{~b}$

Total weyint

$$
781 \mathrm{kf}
$$

Assume the center of gravity of the axombly is at the center of the leak detecter bax (conservative).

This is at a height of 34-in. above the concrete block (the ares of the bore is 14 -in. width $\times 16$-i ni hight $\times 6$-in thick).

BD -6400-060.1 (07/93) 


$$
\text { HNF-4348, Redo }
$$

ANALYTICAL CALCULATIONS

Page 11 of 24

Subject Portable Le Mk Detertra Staten

Originator

Checker Hagen H. Zing

Date

Date

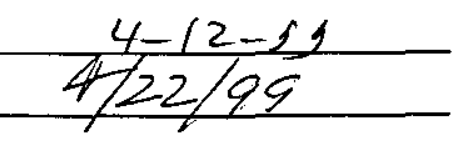

Concrete weight $=\left(\frac{6}{12} \times \frac{8}{12} \times \frac{32}{12}\right) 150 \mathrm{pcf} \times 2=267 \mathrm{lb} \mathrm{f}$

4.3.2 Areas

The assembly is considered as an open sign recording to the definitions of $A S C E 7-9 S$ (1995).

Gross area excluding concrete $=\frac{20 \times 42}{144}=5.833 \mathrm{ft}^{2}$

Estimated solid projected area without concrete $A f=$ Box area + channels

$$
=\frac{14 \times 16}{144}+\frac{2 \times 42+2 \times 20}{144} \times 1.625=2.95 \mathrm{ft}^{2}
$$

Area of concrete ${ }^{\prime \prime} A_{c}^{\prime}=\frac{2 \times 8 \times 6}{144}=0.667 \mathrm{ft}^{2}$

The opening is more than 30 percent of the gross area.

Ratio of solid area/gross area $=\frac{2.95}{5.833}=0.5$

Force coefficient " $C F "=1.6$

Table 6-9 of ASCE(1995).

BD -6400-060.1 (07/93) 
HNF - 4348, Rer.o

ANALYTICAL CALCULATIONS

Page 12 of 24

subject Portable LeM Detection station

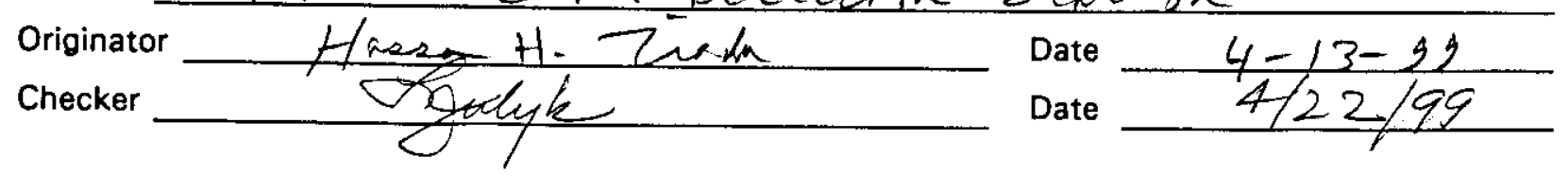

4.3 .3 Seismic Loads

The seismic had for PCP hoo been calculated in accordance with HNF(19,7) and $U B C(1994)$.

HNF (1997) specifies that eire th quake hod design of PCI SSCS shall comply with UBC, seismic zone 28 for standard occupancy facilities.

static tooth lateral force " $F_{b}$ " is:

$$
F_{b}=Z I C_{p} W_{p}
$$

where:

$$
\begin{aligned}
& z=0.2 \mathrm{~g} \\
& I_{1}=1.0 \\
& c_{p}=1.5
\end{aligned}
$$

seismic zoe $2 B$

Importance factor for standard occupancy.

Horizontal force factor for

flexible structure $(2.0 \times 0.75)$.

Horizontal seismic lond on bracket " $F_{b}$ " is:

$$
F_{b}=0.2 \times 1.0 \times 1.5 \times 78=23.4 \mathrm{lb} f
$$

Horizontal seismic loud ion concrete footing " $F_{c}$ " is:

$$
F_{c}=0.2 \times 1.0 \times 1.5 \times 2.67=80.116 \mathrm{f}
$$

BD-6400-060.1(07/93) 


$$
\text { HNF }-4348, \text { Rer.o }
$$

ANALYTICAL CALCULATIONS

Page 13 of 24

subject Portable lenk Detection stition

Originator

Haser H. Tialo

Checker
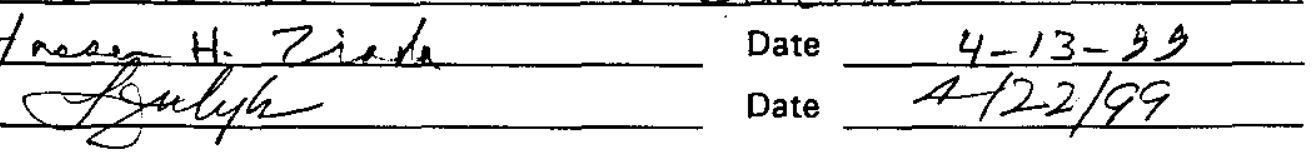

4.3.4 Wind Loads

The wind loads for PC3 structure has been calculatal in accordance with HNF (1997) and ASCE 7-9S (1935).

$$
q_{z}=0.00256 k_{z} k_{z t} V^{2} I
$$

$I=1.0$ importance fuctor, $P R 0-097(1997)$.

$V=100$ MPH Guat wind, PR0-097 (1537).

$K_{z}=0.85$ for exposure Cutejory $C$, ASCE(1995).

(Table 6-3)

$$
\begin{aligned}
& k_{z t}=1.0 \quad \text { section 6.5.5, AscE(1995) } \\
& q_{z}=0.00256 \times 0.85(100)^{2} \times 1.0=21.76 \mathrm{lb} / \mathrm{ft}^{2}
\end{aligned}
$$

Wind Force:

$$
F=q_{z} G C_{f} A f
$$$$
G=0.85 \text { For exposwre. Catyary C, ASCE (1355), }
$$
section 6-6.1.

$C_{f}=1.6$ For salidwrea/grossareen betroen 0.3 to 0.7 Table 6.9, ASCE (1995).

$$
F_{w}=21.76 \times 0.85 \times 1.6 \times 2.95=.87 .3 \quad 16 \mathrm{f} \approx 881 \mathrm{f}
$$

Wind lood governs.

$>23.416 \mathrm{f}$ seris nine

BD-6400-060.1 (07/93) 
HNF- 4348, Rer.o

ANALYTICAL CALCULATIONS

Page 14 of 24

subject Portable Leak Detection Station

Originator

Checker Iowan H. Turn

Date

Date $4-13-98$
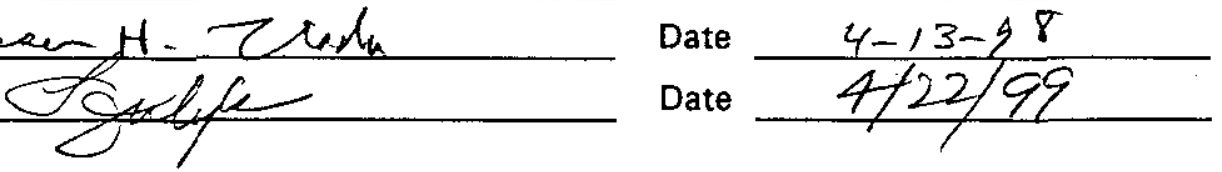

5.0 ANALYSIS

The overturning and sliding have been evaluated for both seismic and wind loads, including the effect of footing concrete.

The bracket assembly has been analyzed for dead weight and wind hood. The stresses and bods were evaluated in accordance with $A / s c(1189)$ and compared to the allowable lords of UNISTRUT (1935).

5.1 OVERTURNING-

5.1 .1 Overturning Due to seismic Loads.

OT Moment a bout $A=23.4 \times 40+80.1 \times 3$

$$
=1,176 \text { in }-16 \mathrm{f}
$$

Resistance Moment $=(78+267) \times 16$

$$
=5,520 \mathrm{in}-1 \mathrm{~b}
$$

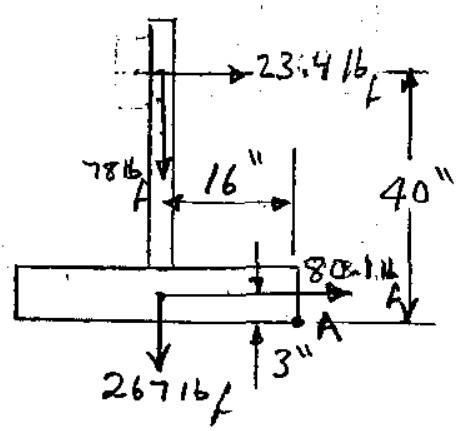

Resist. Moment > OT moment.

station will not overture.

BD-6400-060.1 (07/93) 
HNF- 4348, Rev. 0

ANALYTICAL CALCULATIONS

Subject

Portable

Page 15 of 24

Originator

Has $H$. ins

Checker

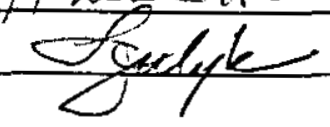

$$
\text { Date }
$$$$
4-14-23
$$

Date

5.1 .2 Overturning Due to wind Loads

$$
\begin{aligned}
\text { Wind Lord on concrete } & =A_{C} \times 21.76 \times 0.85 \times 1.6 \\
& =0.667 \times 21.76 \times 0.85 \times 1.6 \\
& =19.716_{C}
\end{aligned}
$$

OT Moment about $A=88 \times 40+19.7 \times 3$

$$
=3579 \mathrm{in}-16 \mathrm{f}
$$

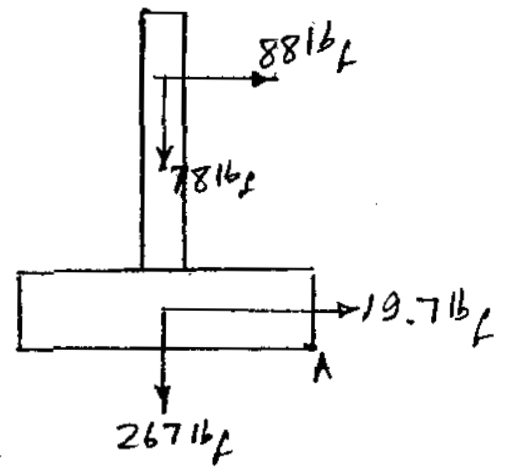

$$
\begin{aligned}
\text { Resistance Moment } & =(78+267) \times 16 \\
& =5,520 \text { in } 162
\end{aligned}
$$

OT Mount $(3,5.29)<\frac{2}{3}$ Resis Mount (UBC, sec.1621)

station will not turnover.

5.2 SLIDING

5.2 .1 SLiding Due to seismic Loads

shitting force $=23.4+80.1=103.51 \mathrm{f} \mathrm{f}$

Coefficient of friction on graved $=0-35 \quad$ (UBC,1954)

Resistance force $=(78+267) \times 0.35=120.751 \mathrm{~b} f$

Resistance force $>$ sliding force.

station will not slide.

INF- 42 VR RoT. 0 
HNF-4348, Rev. 0

ANALYTICAL CALCULATIONS

Page 16 of 24

subject Portable Leak Detector station

Originator

Checker neschi. Jim

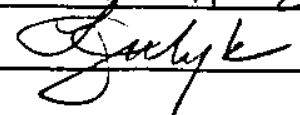

Date

Date $\frac{4-14-99}{4 / 22 / 99}$

5.2 .2 sliding Due to wind Loads

sliding force $=88+13.7=101.7 \mathrm{lb} f$

Resistance force $=(78+267) 0-35=120.75 \mathrm{lb} /$

Resistance force $>$ shading force

station will nt slide

5.3 ChanNel stresses (PIO01)

The dimensions and loads are shown ni Figure l.

The maximum bending moment is Taken at the base of the vertical charrals'(point $A$ in Figure 1).

$$
\text { Moment about } \begin{aligned}
A & =88 \times 34+78 \times 4.62 \mathrm{~s} \\
& =3,353 \mathrm{in}-1 \mathrm{~b} \mathrm{a}
\end{aligned}
$$

$$
\begin{aligned}
& \text { Bending stress " } \sigma_{b} \text { " }=\frac{M_{A}}{25_{11}} \quad \text { (twochunnels) } \\
& \sigma_{b}=\frac{3,353}{2 \times 0.572}=2,931 \mathrm{lb} \mathrm{f} / \mathrm{in}^{2}
\end{aligned}
$$

Less than $\sigma_{b}$ allowable $<19,80016 \mathrm{f} / \mathrm{in}^{2}$

BD-6400-060.1 (07/93) 


$$
\text { HNF - 4348, Rev }
$$

ANALYTICAL CALCULATIONS

Page 17 of 24

Subject Portable Leak Detector Station

Originator

Checker \#rszar H. Ziska

Date

Date
$4-14-39$

$4 / 22 / 99$

5.4 FITTING SCREWS STRESSES

The configuration of the ninety degree angle fitting (P 2484) is shown below. The screens are $1 / 2$-in dimeter.

Assume the moment at point 0 , is carried by the fer the at screw only (see Figure 1).

$$
\begin{aligned}
M_{O_{1}} & =88 \times 34+78 \times 6.25 \\
& =3,480 \mathrm{in}-1_{\mathrm{F}}
\end{aligned}
$$

Area of $1 / 2$-in. screw $=\frac{\pi(0.5)^{2}}{4}$

$$
=0.196 \mathrm{in}^{2}
$$

Axil lord in screw " $F_{B}^{\prime \prime}=\frac{3,480}{3.25}=1,071 \mathrm{l}^{16} \mathrm{~F}$

Axil stress $=\frac{1,071}{2 \times 0.196}=2,732 \mathrm{lb} / \mathrm{in}^{2}$ (two balt for tho columns)

Less than allowable trace stress $<19,800 \mathrm{lbf} / \mathrm{in}^{2}$

The pull and shea throbs are las them the UNISTRUT allowable lords of $2,000 \mathrm{lb}$ and $1,500 \mathrm{l} / \mathrm{f}$, respectively.

$$
\text { NF- } 4348 \text {, Rev. } 0
$$

ANALYTICAL CALCULATIONS

Page 18 of 24 
HNF-4348, Rer.0

ANALYTICAL CALCULATIONS

Page 18 of 24

subject Portable Leak Detector station

Originator

Checker Happen $H_{1}$ Zine Date $4-14-39$

Date $4 / 22 / 99$

SIS WELD STRESSES

See Figure l for laps and dimensions.

The two horizontal channels are carrying the total weights (conservative, became only the box lords are taken by the welds). The bottom 3/32 -in. Fillet welds are the critical weld.

Assume the two horizons channels are fixed beams at the ends and blooded at the middle (conservative).

Moment at the fixed end of the beam:

$$
M_{y}=\frac{P l}{2 \times 8}=\frac{88 \times 16.75}{16}=92 \mathrm{in}-1 \mathrm{~b} \mathrm{f} \text { (two beams) }
$$

Use Blodgett (1982) for weld andy s is, neglect the top weld.

sheer $F_{s y}=\frac{78}{4} \simeq 20 \mathrm{bf} / \lim$ in

sher. $f_{s x}=\frac{88}{4}=2216 \mathrm{f} /$ him in

$$
\begin{aligned}
T=M_{Z}= & \text { Moment of } 7816 \mathrm{f} / \mathrm{hi} \\
+ & \text { Moment of } 881 \mathrm{~b} \mathrm{f} \\
& \text { on: the vertical side }
\end{aligned}
$$

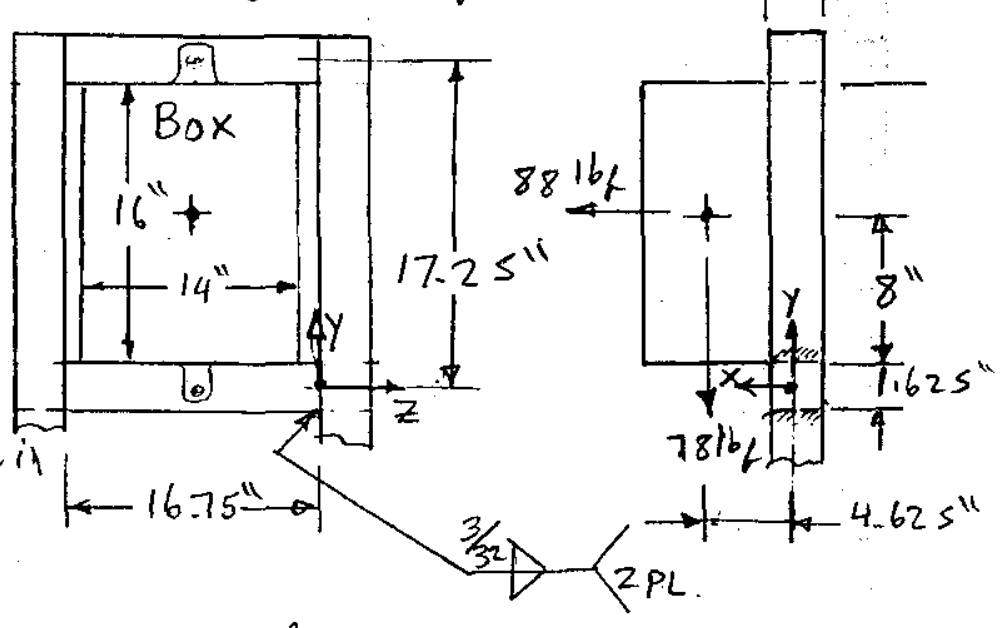
of the channels as beams with fixed ends.

$$
\text { Twist } T=\frac{78 \times 4.625}{2}+\frac{88 \times\left(8+\frac{1.625}{2}\right)}{2}=568 . \quad \text { in -16 } \mathrm{f}
$$

(neglect upper beam)

BD -6400-060.1 (07/93) 
IN F- 4348 , ReV .O

ANALYTICAL CALCULATIONS

Page 19 of 24

subject Portable Leak Detector stat om Originator Hansen H. Z iva

Checker Date $\frac{4-14-93}{4 / 22 / 99}$

$A_{\omega}=2 b=6.5 \mathrm{in} / \mathrm{lim} \mathrm{in}$

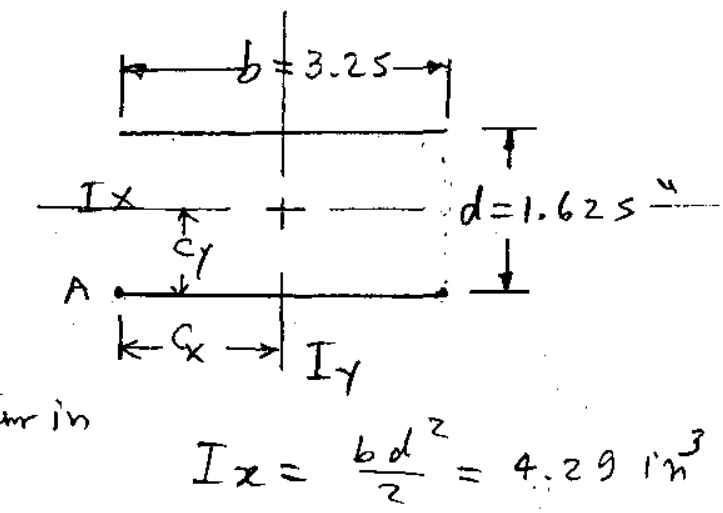

$s_{x}=b d=5.28 \mathrm{in}^{2} /$ liner in

$s_{y}=\frac{b^{2}}{3}=3.52 \mathrm{in}^{2} /$ mimer in

$J=\frac{d}{6}\left(3 b^{2}+d^{2}\right)=9.3 \mathrm{in} 3 /$ him in

$$
I_{x}=\frac{b d^{2}}{2}=4.29 \mathrm{in}^{3}
$$

Find the resultant shear Force $\left(F_{r}\right) . \quad I_{y}=\frac{b^{3}}{6}=5.72$

tension $f_{t_{z}}=\frac{M y}{s y}=\frac{92}{3.52}=26$.

m. twist $f_{t_{x}}=\frac{T C_{x}}{J}=\frac{586 \times \frac{3.25}{2}}{9.3}=102 \mathrm{~b} \mathrm{w}_{\mathrm{f}_{t y}}^{f_{s y}}$<smiles>CC(C)(C)C1(C(F)(F)F)CCCCCC1</smiles>

vert twist $f_{t y}=\frac{T C_{y}}{J}=\frac{586 \times \frac{1.625}{2}}{9.3}=51 \mathrm{~b} \mathrm{f} / \mathrm{in}$

$$
f_{r}=\sqrt{\left(f_{s y}+f_{t y}\right)^{2}+f_{t_{z}}^{2}+\left(f_{s x+}+f_{t x}\right)^{2}}=\sqrt{(71)^{2}+(26)^{2}+(724)^{2}}
$$

$f_{r}=145 \mathrm{lb} /$ linear inch.

Assume weld is mad of Ex 0070 with 70,000 $16 \mathrm{fl} / \mathrm{in}^{2}$ Ultimate strength.

Allowable shear loot $=0.3 \times 70,000 \times 0.707 \times \frac{3}{32}$

$=928 \mathrm{lb} /$ lear inch.

Weld is acceptable.

BD-6400-060.1 (07/93) 
HNF-4348, Rev.0

ANALYTICAL CALCULATIONS

Page 20 of 24

subject Portable Leak Detection stand

Originator

Haze H, Zine

Checker Date $\frac{4-14-99}{\frac{4 / 22 / 99}{2}}$

5.6 MISSILE IMPACT

The PC 3 structure needs to beanntyged for a wind-generatad missile defined as a $2 \times 4$-in timber plunk weighing is $1 b_{f}$ impacting on end with a velocity of $56 \mathrm{mph}$ (HNF 1997). The analysis followed the guideline provided in Bechtel (1974).

The equivalent diameter (D) of the missile is defined as diameter of a circle with an area equmilent to the impact ares (or projected frontal area) of the nou-cylindrical missile:

Thickness of $2 \times 4$ plunk $=1.5$ in

Width of $2 \times 4$ plunk $=3.5$ in

Area of plank $=1.5 \times 3.5=5.25 \mathrm{in}^{2}$

Equitant diameter (D) $=\sqrt{\frac{4 A_{p}}{\pi}}=2.585$

Velocity $\left(V_{s}\right)=50 \mathrm{mph} \times \frac{1760 \times 3}{3600}=73.33 \mathrm{ft} / \mathrm{sec}$.

$\operatorname{plankm\text {mes}}(M)=\frac{\omega}{g}=\frac{15}{32.2}=0.466 \mathrm{~kg} \cdot \mathrm{sec}^{2} / \mathrm{pt}$

BD -6400-060.1 (07/93) 
HNF - 4348, Re wo

ANALYTICAL CALCULATIONS

subject Portable Leak Detector Station

Page 21 of 24

Originator

Checker Date $\frac{4-14-94}{4 / 22 / 99}$

The box that contains the leak detector instrument is 14 gouge thither s $(0.083-$ in $.8 W G)$.

The formula provided in Bechtel $(18>4)$ for steed plate thickens es $(T)$ which will just be perforated by the missile is:

$$
\begin{aligned}
T & =\frac{\left(\frac{M V_{s}^{2}}{2}\right)^{2 / 3}}{672 D}=\frac{\left(\frac{0.466 \times(73.33)^{2}}{2}\right)^{0.666}}{672 \times 2.585} \\
& =0.0669 \mathrm{in}
\end{aligned}
$$

Wall thickness (t $p$ ) required to prevent perforation shade be $1.25 T$.

$$
t_{p}=1.25 \times 0.0669=0.0836 \text { in } \approx 0.083 . \mathrm{in}
$$

The box almost mikes it (ire., it is acceptable).

$$
\text { 6.O OPEN. ITEMS }
$$

There are no open items related to this and ty sis.

BD-6400-060.1 (07/93) 
HNF- 4348, Rev.0

ANALYTICAL CALCULATIONS

Page 22 of 24

Subject

Portable Leak Detector Stitum

Originator

Checker Date $\frac{4-14-53}{4 / 2}$ Date $4 / 22 / 89$

THO REFERENCES

AISC, 1989," Manual of Steel Construction, Allowable stress Design," American Institute of steed construction Inc., Chicer, Illinois.

ALE 795999 M Min mum Design Loads for Buildings Hand other Structures" ASCE 7-95, American society of Curl Engineers, News York, New York.

ASTM, 1995," Annual Book of ASTM Stenderds," American Society of Testing and Materials, Philadelphia, Pennsylvania.

BLodgett, 0.W.1982," Design of Welded structures, James F. Lincoln Arc welding Foundation, Cleveland, ohio.

Bechtel, 1974, "Design of structures for Missile Impact," Topical Report, BC-TOP-9A, Reva, September 1974, Bechtel Power Corporation, San Francisco, California

DOE 6430.1A, 1989 , "General Design Criteria," Order DOE 6430.1A, US Department of Energy, Washing th, D.C.

BD -6400-060.1 (07/93) 
HN F- 4348 , Rer.o

ANALYTICAL CALCULATIONS

Page 23 of 24

subject Portable Leak Detection statim:

Originator

Checker

Hasa H. Ziah Date $-4-14-12$

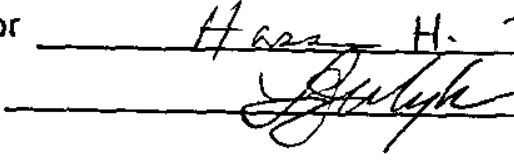
Date $4 / 22 / 99$

ECN, 1559,"Portable Leak Detection Station,"

Englneering Change Notice (ECN) \#652131, Lockheed Martin Hanford Company, Richlmad, WA.

LMHC, 1959,"Leak Detector A s embly Typical Detrits,"

Drg \# H-2-34565, Lockheed Martin Hanfard,

Richlunt, washingtra.

HNF, 1997, "Engineering Design Evaluatem," Project

Hanford Procedures, HNF - PRO-097, Rer-0, Fluor

Daniel 1 anford, Richland, Waskingtm.

Timmins, D.C., 1998," Clarification Regarding the Seismic Sofety Analysis," Inter affice Memo 74700-98-DCT-037, HNF-5D-WM-B10-001, September 24, 1998, Loekheed Martin Haiford Compary, Richlaud Wastingtom.

$\forall B C, 1994$," Uniform B widing Code," Inter mational Conference of Bulting officiils, whittier, Califorrie.

BD.6400-060.1 (07/93) 


$$
\text { INF }-4348-\text { Rer.o }
$$

ANALYTICAL CALCULATIONS

Page 24 of 24

Subject Portable Leak Detection station

Originator

Checker Date Date $4 / 22 / 99$

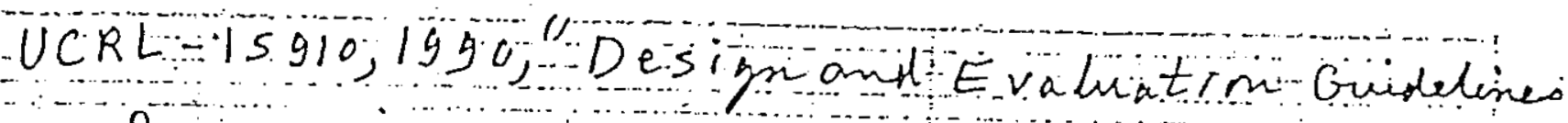

for Department of Energy Facilities to Natural Phenomena- Hazards U.CRL-15910; University of Culifarine Research Laboratory, Livermore, California.

UNISTRUT, 1995, "UNISTRUT. Metal Framing, General Engineering Catalogue," Unistrut Diversified Products, Wayne, Michigan.

WHC, 1993,"Footing-Concrete, "Drawing \# H-2-815302, Rev.0, Westing house Hanford Company, Richlend, Washington.

BD -6400-060.1 (07/93) 


\section{DISTRIBUTION SHEET}

To

Distribution

Project Title/Work Order

Analysis of Bracket Assembly for Portable Leak Detector station (HNF-4348)

\begin{tabular}{|l|}
\hline \\
\hline M. G. Al-Wazani \\
\hline L. J. Julyk \\
\hline L. S. Krogsrud \\
\hline R. E. Larson \\
\hline P. C. Miller \\
\hline W. J. Powell \\
\hline R. W. Reed \\
\hline S. H. Rifaey \\
\hline R. L. Schlosser \\
\hline J. P. Sloughter \\
\hline R. R. True \\
\hline J. J. Verderber \\
\hline H. H. Ziada \\
\hline
\end{tabular}

From
Operational Equipment Engineering

Date May 4, 1999

EDT No. 624016

ECN No. 652131

\section{Name}

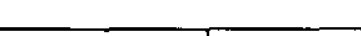

